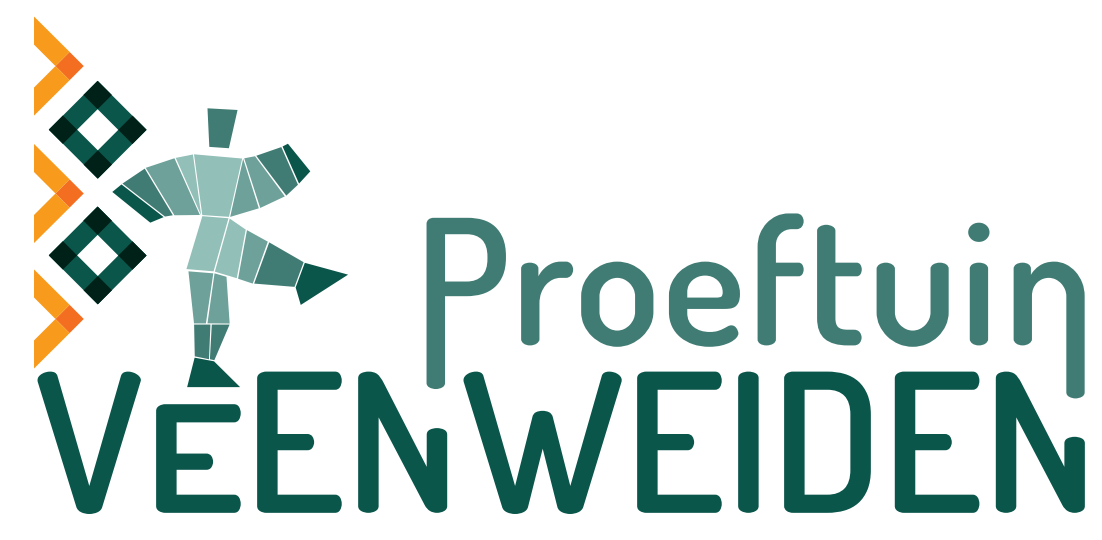

\title{
Naar een integraal gebiedsgerichte aanpak om ammoniakemissie te reduceren \\ Ontwerp en pilot
}

Marieke van Leeuwen, Gerard Migchels en Leo Joosten

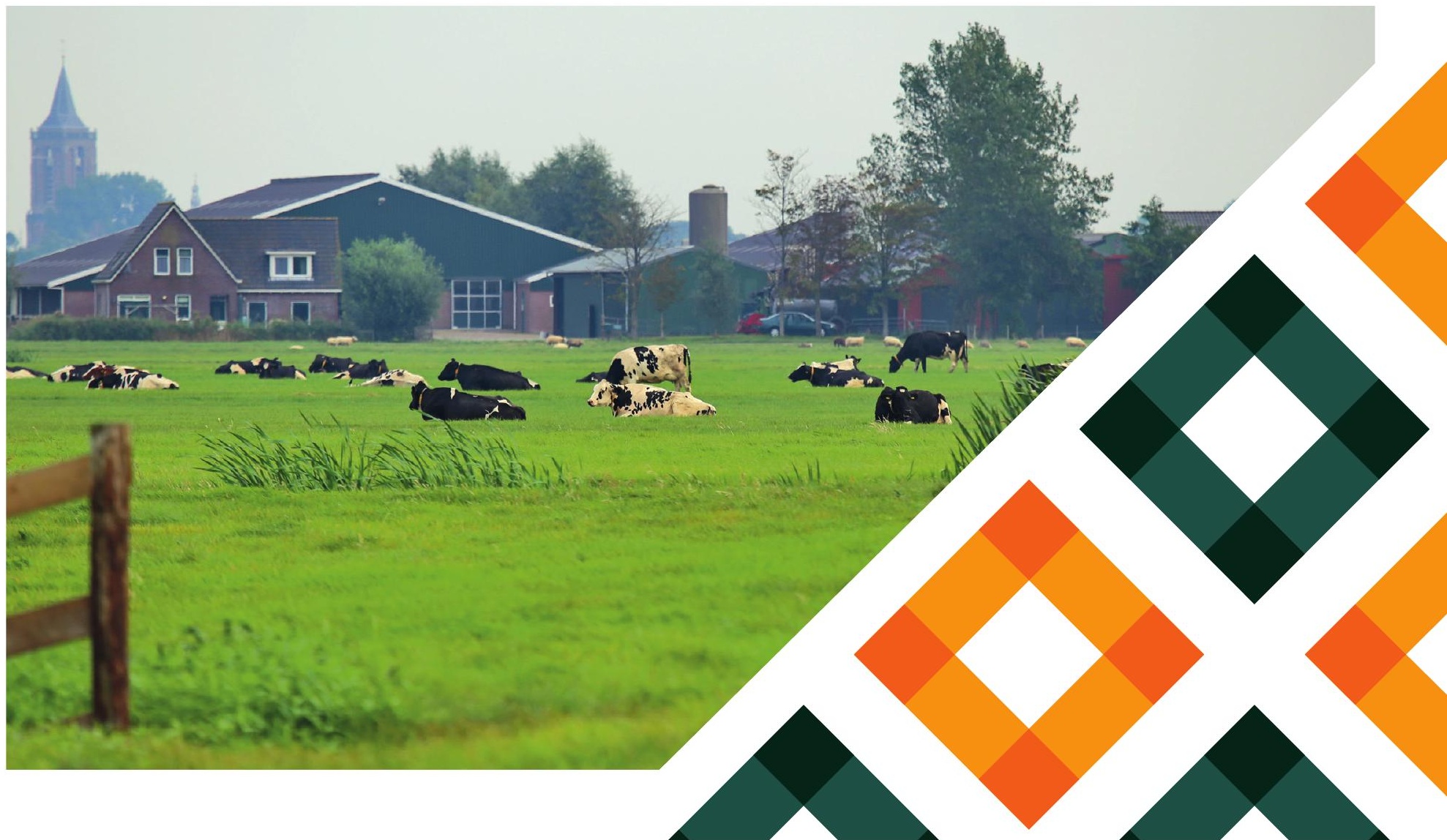





\section{Naar een integraal gebiedsgerichte aanpak om ammoniakemissie te reduceren}

Ontwerp en pilot

Marieke van Leeuwen, Gerard Migchels en Leo Joosten

1 Projecten LTO Noord

2 Wageningen Livestock Research

3 ORG-ID

LTO Noord startte begin 2016 met het innovatieprogramma Proeftuin Veenweiden en wordt daarbij financieel ondersteund door provincie Zuid-Holland, het Ministerie van Economische Zaken, het Melkveefonds en het LTO Noord Fonds. De Proeftuin is een initiatief van LTO Noord en VIC Zegveld. De uitvoering van het programma is in handen van LTO Noord, Wageningen University \& Research, VIC Zegveld, PPP-Agro Advies, ORG-ID en het Louis Bolk Instituut.

Wageningen Livestock Research

Wageningen, augustus 2019

Rapport 1198 
Marieke van Leeuwen, Gerard Migchels en Leo Joosten, 2019. Naar een integraal gebiedsgerichte aanpak om ammoniakemissie te reduceren; Ontwerp en pilot. Wageningen Livestock Research, Rapport 1198.

Dit rapport is gratis te downloaden op https://doi.org/10.18174/500790 of op www.wur.nl/livestock-research (onder Wageningen Livestock Research publicaties).

(C) 2019 Wageningen Livestock Research

Postbus 338, 6700 AH Wageningen, T 03174839 53, E info.livestockresearch@wur.nl, www.wur.nl/livestock-research. Wageningen Livestock Research is onderdeel van Wageningen University \& Research.

Wageningen Livestock Research aanvaardt geen aansprakelijkheid voor eventuele schade voortvloeiend uit het gebruik van de resultaten van dit onderzoek of de toepassing van de adviezen.

Alle rechten voorbehouden. Niets uit deze uitgave mag worden vermenigvuldigd en/of openbaar gemaakt worden door middel van druk, fotokopie, microfilm of op welke wijze dan ook zonder voorafgaande toestemming van de uitgever of auteur.

Wageningen Livestock Research is NEN-EN-ISO 9001:2015 gecertificeerd. Op al onze onderzoeksopdrachten zijn de Algemene Voorwaarden van de Animal Sciences Group van toepassing. Deze zijn gedeponeerd bij de Arrondissementsrechtbank Zwolle.

Wageningen Livestock Research Rapport 1198 


\section{Inhoud}

$\begin{array}{ll}\text { Samenvatting } & \mathbf{5}\end{array}$

1

$\begin{array}{ll}\text { Inleiding } & \mathbf{7}\end{array}$

$\begin{array}{lll}1.1 & \text { De ambities van de Proeftuin Veenweiden } & 7\end{array}$

1.2 Prikkels voor het nemen van bovenwettelijke maatregelen 7

1.3 Naar een pilot voor een integraal gebiedsgericht arrangement 7

$\begin{array}{lll}1.4 & \text { Doelstelling } & 8\end{array}$

$\begin{array}{llr}1.5 & \text { Leeswijzer } & 8\end{array}$

$2.1 \quad$ Verkenning mogelijke inbedding in ANLb (voorjaar 2017) 9

2.2 Samenwerking met Waterpakket AGV 9

2.3 Samenstellen pakket (voorjaar/zomer 2017) en ontwerp puntensysteem/premiestelsel (najaar 2017) 9

2.4 Werving deelnemers en verkenning (najaar 2017) 9

2.5 Uitvoering van de pilot (2017 -2019) 10

2.6 Monitoringsronde (zomer 2018 en winter 2018) 10

3

$\begin{array}{ll}\text { Resultaten } & 11\end{array}$

3.1 Systematiek naar voorbeeld van ANLb 11

3.2 Invulling van het duurzaamheidspakket $\quad 11$

$\begin{array}{lll}3.3 & \text { Beloningssystematiek } & 14\end{array}$

$\begin{array}{lll}3.4 & \text { Monitoring } & 14\end{array}$

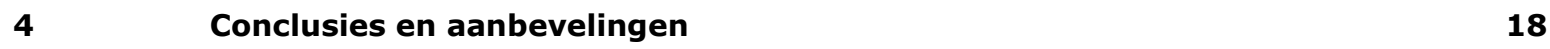

$\begin{array}{lll}4.1 & \text { Conclusies } & 18\end{array}$

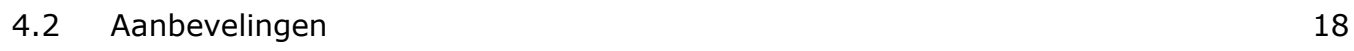

$\begin{array}{ll}\text { Bronnen } & \mathbf{2 0}\end{array}$

$\begin{array}{lll}\text { Bijlage } 1 \quad \text { Deelnemerslijst pilot } & 21\end{array}$

Bijlage 2 Vragen en aanbevelingen n.a.v. gesprek met deelnemers 22

Bijlage $3 \quad$ Analyse met deelnemers pilot Pakketten $\quad 24$

Bijlage $4 \quad \mathrm{NH}_{3}$ prestaties Pilot Duurzaamheidspakketten 26

Bijlage $5 \quad$ Selectie van maatregelen voor het duurzaamheidspakket 27 



\section{Samenvatting}

Het doel van een integrale gebiedsgerichte aanpak

Het doel van de integrale, gebiedsgerichte aanpak is om zoveel mogelijk boeren te motiveren hun bedrijfs-voering te verduurzamen via integrale management maatregelen. Dit is uitgewerkt in de vorm van een "Duurzaamheidspakket": een keuzemenu op bedrijfsniveau, in twee varianten: een doelgerichte en een middelgerichte variant. De inzet is in beide varianten meervoudig: vermindering van ammoniakemissie, verbetering van waterkwaliteit, vermindering van bodemdaling en vergroting van biodiversiteit.

Doelen en maatregelen in het duurzaamheidspakket Op basis van effectiviteit, integraliteit en borgbaarheid zijn deze doelen opgenomen in het keuzemenu:

- P-bodemoverschot en N-bodemoverschot

- Ammoniak Veldemissie en stal/mestopslagemissie

- $\quad \mathrm{CO} 2$ reductie (via regelbare onderwaterdrainage)

- Effect op weidevogels

Op basis van dezelfde overwegingen zijn onderstaande maatregelen opgenomen:

- Verlagen TAN (Totaal Ammoniakale Stikstof)

- Verdunnen mest met water bij aanwenden

- Uitrijtijd drijf- en kunstmest

- $\quad \mathrm{N}$ gift als vaste mest

- Mest- en baggervrije zones langs sloot en greppel

- Geen P kunstmest (alleen voor bedrijven die geen gebruik maken van derogatie)

- Geen P bodemoverschot

- Niet scheuren van grasland/ geen graslandvernieuwing

Stimulerende methodiek

Vervolgens is een methodiek ontwikkeld om goed gedrag te belonen, waarbij de deelnemers afhankelijk van de mate waarin het doel wordt behaald of de mate waarin de maatregel wordt uitgevoerd, worden beloond. Voor alle doelen en maatregelen is ook de wijze van monitoring en borging verkend.

\section{Een pilot van 1 jaar}

Om praktijkervaring op te doen en de aanpak op basis daarvan verder te verbeteren is in 2018 de Pilot Duurzaamheidspakket uitgevoerd in samenwerking met de Stichting Gebiedscoördinatie Gouwe Wiericke en 10 boeren nabij Woerden/ Bodegraven. Het betreft daarmee een pilot van slechts 1 jaar. Dat levert per definitie slechts een indicatie op hoe de aanpak zou kunnen werken. De extreme droogte in het proefjaar 2018, maakt het nog lastiger om conclusies te trekken. Wel kan lering worden getrokken inzake de systematiek.

Inzetbaarheid/ wenkend perspectief van de pakketten-aanpak

De uitkomsten van de pilot zijn bruikbaar als input voor een aantal lopende sporen:

- Brede uitrol via het GLB. Dit kan een interessant spoor zijn om het 'peloton' te bereiken.

- Uitrol via zuivelondernemingen.

- Regionale uitrol via het ANLb, met ruimte voor de boer als sparringpartner voor maatwerk.

- Voor specifieke gebieden met specifieke opgaven. Bijvoorbeeld als een waterschap in een deelstroom-gebied waterkwaliteitsproblemen wil oplossen of als een provincie nabij een N2000 gebied de depositie van ammoniak wil beperken. 
Focus op meest kansrijke maatregelen

Ondernemers bleken beter te prikkelen via het maatregelenspoor dan via het doelenspoor. Verder was men van mening dat je beter op de 5-6 meest effectieve maatregelen kunt focussen in plaats van op 14:

- $\quad$ Een (gemiddeld $10 \%$ ) lagere TAN (borging via KLW)

- De mest 1:1 met water verdunnen (borging via volume meter of EC-meter i.c.m. een datalogger)

- Gemiddeld 500 uur meer weidegang (borging via CO2 meter in de stal)

- Minder kunstmest en het niet te laat uitrijden van kunstmest

- Sturen van grondwaterpeil met behulp van onderwaterdrainage

- $\quad$ Netjes \& op juiste moment uitrijden (borging via GPS i.c.m. datalogger, verder uit te werken) 


\section{$1 \quad$ Inleiding}

\subsection{De ambities van de Proeftuin Veenweiden}

De Proeftuin Veenweiden heeft als ambitie een vermindering van de ammoniakemissie in het westelijke veenweidegebied van 1,5 - 2,6 kton in 2030. Dat komt overeen met een vermindering van de emissie op bedrijfsniveau van $25-40 \%$. Bij voorkeur moeten deze oplossingen ook bijdragen aan oplossing van andere problemen in het veenweidegebied, zoals onvoldoende waterkwaliteit, bodemdaling en beperkte biodiversi-teit. En het is de ambitie om, via transacties, bij te dragen aan ruimte voor ontwikkeling van andere sectoren.

\subsection{Prikkels voor het nemen van bovenwettelijke maatregelen}

De Proeftuin onderzoekt daartoe mogelijke bovenwettelijke maatregelen, onderbouwt deze en toetst deze aan de dagelijkse praktijk van melkveebedrijven ('pilotboeren'). Maar de Proeftuin is pas geslaagd als deze bovenwettelijke maatregelen ook kans maken om op grote schaal te worden geïmplementeerd.

De eerste route daartoe loopt via het zoeken naar economische en praktische voordelen van maatregelen. Veel ammoniak reducerende voer- en managementmaatregelen leiden in potentie al tot lagere kosten of hogere baten. Dat maakt ze aantrekkelijk. Een tweede route loopt via arrangementen, waarbij andere partijen verleid worden om (uit welbegrepen eigenbelang) de melkveehouder (financieel) tegemoet te komen, als deze bovenwettelijke maatregelen neemt. Dat gebeurt alleen als er sprake is van win-win.

In het rapport "Eerste verkenning arrangementen om ammoniakemissie in het westelijk veenweidegebied te reduceren" (Migchels, van Leeuwen \& Joosten, 2019) zijn 3 potentiële win-win arrangementen beschreven: Integraal gebiedsgericht, ketengericht en depositiegericht. Dit rapport werkt het integrale gebiedsgerichte arrangement verder uit.

\subsection{Naar een pilot voor een integraal gebiedsgericht arrangement}

In het veenweidegebied blijken sommige maatregelen om ammoniakemissie te reduceren ook bij te dragen aan verbetering van waterkwaliteit, tegengaan van bodemdaling en terugdringen van $\mathrm{CO} 2$ uitstoot. De optelsom leidt dan tot extra maatschappelijke winst. Is het mogelijk om agrariërs te verleiden maatregelen te nemen die bijdragen aan meerdere doelen, via het afsluiten van "beheer"pakketten, met een beloning in de vorm van een premie? Een achterliggende vraag is of een dergelijke systeem geschikt zou kunnen zijn voor grootschalige uitrol van integrale managementmaatregelen.

Om een dergelijke aanpak praktijkrijp te krijgen, moeten de volgende vragen worden beantwoord:

- Hoe zou je een integrale gebiedsgerichte benadering kunnen uitwerken als een groenblauwe dienst met een bijbehorende financiële vergoeding?

- Welke doelen en maatregelen horen daarbij?

- Hoe ontwerp je een laagdrempelige en eenvoudige methode, die recht doet aan de behoefte aan maatwerk per bedrijf en keuzevrijheid per ondernemer?

- Hoe hoog zou die beloning moeten zijn om voldoende aantrekkelijk te zijn?

- Kan het nemen van die maatregelen afdoende worden geborgd? 
Daartoe is de pilot "Duurzaamheidspakket" uitgevoerd in samenwerking met de Stichting Gebiedscoördinatie Gouwe Wiericke en 10 melkveehouders nabij Woerden/ Bodegraven. In dit rapport wordt de bevindingen uit deze pilot beschreven.

\section{$1.4 \quad$ Doelstelling}

Het doel van de Pilot is om een flexibel keuzemenu met bijpassend premiestelsel te ontwerpen en in de praktijk te toetsen, waarmee agrariërs gestimuleerd worden om maatregelen te nemen die bijdragen aan vermindering van de ammoniakemissie, verbetering van de waterkwaliteit en biodiversiteit, tegengaan van bodemdaling en terugdringen van $\mathrm{CO} 2$ uitstoot.

\subsection{Leeswijzer}

In hoofdstuk 2 is de aanpak van de pilot beschreven. Hoofdstuk 3 beschrijft de uitkomsten. En hoofdstuk 4 bevat conclusies en aanbevelingen. 


\section{Aanpak}

Om te komen tot een werkbare systematiek zijn de volgende stappen doorlopen:

\subsection{Verkenning mogelijke inbedding in ANLb (voorjaar 2017)}

Agrarische collectieven hebben veel ervaring met Agrarisch Natuur- en Landschapsbeheer (ANLb)pakketten zoals baggerspuiten, ecologisch slootschonen en bemestingsvrije bufferzones. Het systeem van deze pakketten sluit goed aan bij de boerenpraktijk en geeft ruimte voor het noodzakelijke maatwerk ${ }^{1}$. In het voorjaar van 2017 zijn in samenwerking met het gebiedscollectief Gouwe Wiericke de mogelijkheden onderzocht om nieuwe pakketten te ontwikkelen op basis van dezelfde systematiek en deze in te bedden in het ANLb. Ook is de mogelijk toekomstige rol van het collectief bij monitoring en borging onderzocht.

\subsection{Samenwerking met Waterpakket AGV}

Onafhankelijk van de Proeftuin Veenweiden, was het Hoogheemraadschap Amstel Gooi en Vecht, samen met een aantal andere partijen ${ }^{2}$ ) bezig met een soortgelijk onderzoek naar een Kringlooppakket, gericht op verbetering van de waterkwaliteit. Het onderzoek heeft zich vertaalt in 2 praktijk-pilots met elk 10 boeren; één in het werkgebied van collectief Rijn Vecht en Venen en één in het werkgebied van collectief Water Land en Dijken. Dit onderzoek vertoonde interessante overeenkomsten met de inzet voor een integraal gebiedsgericht arrangement binnen de Proeftuin Veenweiden. De aanpak en voortgang is daarom regelmatig gezwaluwstaart.

\subsection{Samenstellen pakket (voorjaar/zomer 2017) en ontwerp puntensysteem/premiestelsel (najaar 2017)}

Allereerst zijn de meest effectieve maatregelen om ammoniakemissie te reduceren, beoordeeld op hun effect op andere doelen. Vervolgens is een selectie gemaakt van maatregelen die meervoudig winst opleveren. Per maatregel zijn vervolgens randvoorwaarden benoemd en mogelijkheden voor borging en monitoring verkend.

Vervolgens is een systematiek ontworpen waarbij de (bovenwettelijke) inzet van de ondernemer wordt beloond met een premie.

\subsection{Werving deelnemers en verkenning (najaar 2017)}

Om de pilot uit te voeren is aangesloten bij een bestaande studiegroep van 10 ondernemers. In deze groep was het vertrouwen aanwezig dat nodig werd geacht voor deze pilot.

\footnotetext{
1 Niettemin ervaren de collectieven wel degelijk drempels bij de uitrol van het ANLb, maar die zijn vooral gerelateerd aan de hoge controledruk die gekoppeld is aan Europese subsidiegelden. De systematiek zelf wordt doorgaans als werkbaar en (vanuit de boer gezien) laagdrempelig beoordeeld.

2 NMI, PPP-Agro Advies en de collectieven Rijn, Vecht en Venen en Water, Land en Dijken in opdracht van provincie NoordHolland, programmabureau Utrecht-West, en de waterschappen Amstel, Gooi en Vecht (AGV), Hoogheemraadschap de Stichtse Rijnlanden (HdSR) en Hoogheemraadschap Hollands Noorderkwartier (HHNK).
} 


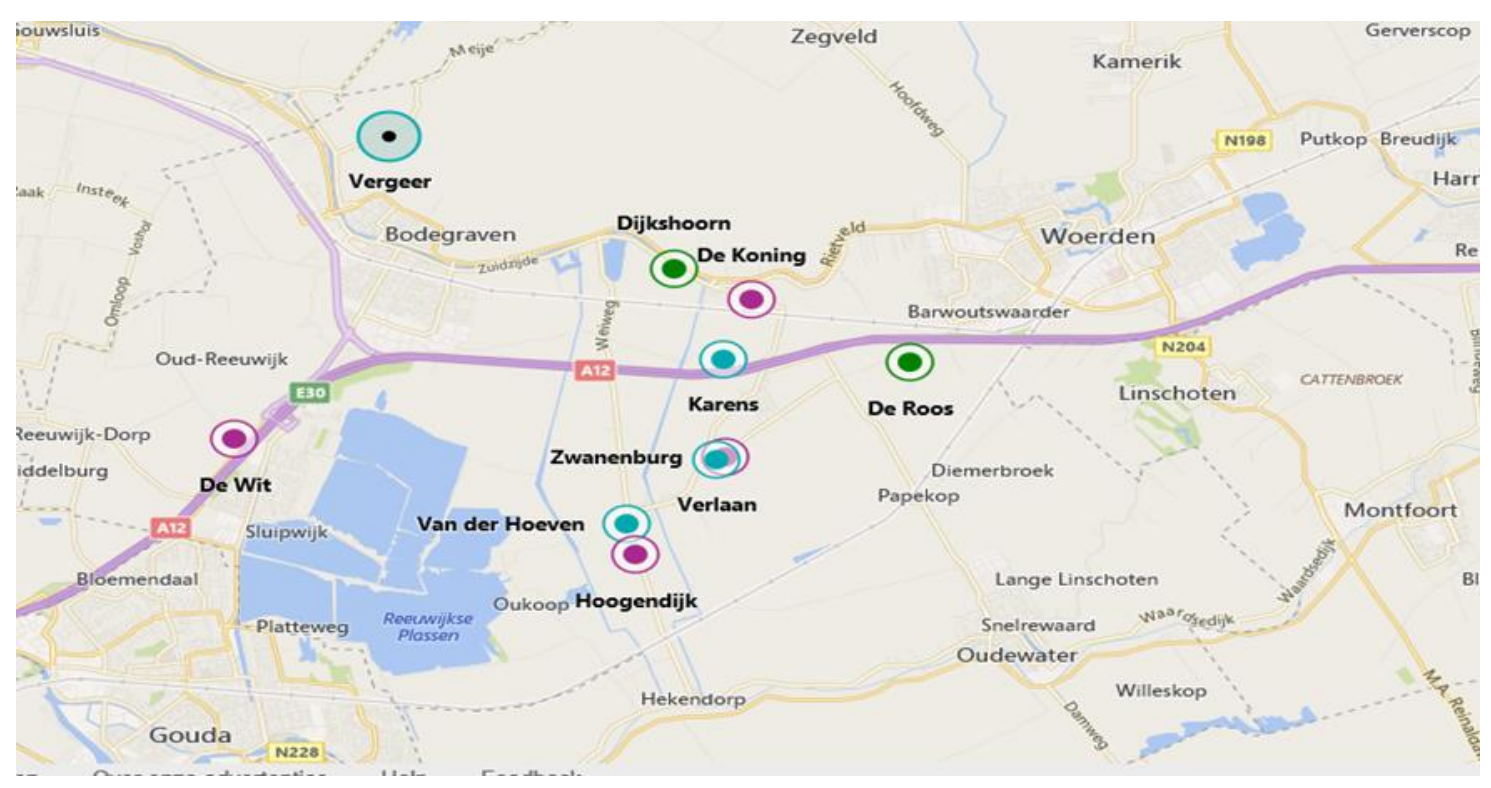

Figuur 1 Deelnemers Pilot Duurzaamheidspakketten.

Deze ondernemers hebben allen een melkveebedrijf op circa $60 \%$ veengrond en $40 \%$ klei- en zandgrond. Op ca. $4 \%$ van de grond wordt mais verbouwd. De rest is grasland. De arealen van de deelnemers lopen uiteen van 28 - 92 ha per bedrijf, de veestapel van 60-150 melk- en kalfkoeien per bedrijf en een melkproductie van 9400-20700 I/ha.

Met deze groep is allereerst een verkenning uitgevoerd naar de werkbaarheid van het uitgewerkte keuze-menu. Zijn de maatregelen toepasbaar? Wat is de gewenste mate van keuzevrijheid/ flexibiliteit? Gaan agrariërs andere managementbeslissingen nemen? Wat zijn de praktische aspecten waarop gelet moet worden bij ontwerp van het pakket? Vervolgens is het ontwerp keuzemenu verder aangescherpt.

\section{$2.5 \quad$ Uitvoering van de pilot (2017 -2019)}

In de winter van 2017/ 2018 zijn vervolgens individuele gesprekken gehouden waarbij de deelnemers, op basis van gewenste ontwikkelingsrichting, bedrijfsspecifieke kenmerken en persoonlijke voorkeuren aan het begin van het jaar een individueel pakket samenstelden van maatregelen die zij zouden willen uitvoeren op hun bedrijf, of van doelen die zij zouden willen behalen.

In het najaar van 2018 zijn wederom gesprekken gevoerd met alle betrokken deelnemers met als belangrijkste vragen of de maatregelen waren uitgevoerd zoals voorgenomen en waarom wel of niet?

Tot slot is in het voorjaar van 2019 een groepsevaluatie gehouden.

\subsection{Monitoringsronde (zomer 2018 en winter 2018)}

$\mathrm{Er}$ is een systeem bedacht voor de monitoring van de verschillende maatregelen. Daarbij is ook gekeken naar de mogelijkheden bij opschaling. In diverse rondes heeft PPP Agro-advies gemonitord bij de 10 deelnemers. 


\subsection{Systematiek naar voorbeeld van ANLb}

Onderzocht is of de keuzepakketten zouden kunnen worden vormgegeven via de systematiek van het ANLb en eventueel zelfs kunnen worden opgenomen in het ANLb. Dat bleek echter vrijwel onmogelijk (zie het kader). Medio 2017 is daarom gekozen de aanpak onafhankelijk van het ANLb verder uit te werken. Het werkingsmechanisme blijft echter wel gebaseerd op het systeem van het ANLb.

Kader: waterpakketten binnen het ANLb

Binnen het Agrarisch Natuur en Landschapsbeheer (ANLb) zijn verschillende waterpakketten ontwikkeld waarbij individuele agrariërs een vergoeding ontvangen voor geleverde "blauwe" diensten. Samen met BoerenNatuur is onderzocht hoe een Kringlooppakket (zie 2.1) zou kunnen passen binnen de kaders van het ANLb (en de door de EU goedgekeurde koppeltabel), opdat:

- dan $50 \%$ cofinanciering mogelijk wordt vanuit de EU;

- contracten voor een langere termijn kunnen worden aangegaan, in principe voor zes jaar;

- $\quad$ het op grote schaal kan worden uitgevoerd (het ANLb is land dekkend);

- er gebruik wordt gemaakt van bestaand samenwerkingsverbanden tussen collectieven en ondernemers.

Dat bleek echter vrijwel onmogelijk. Grootste knelpunten:

- $\quad$ ANLb pakketten worden op perceelniveau afgesloten en kringlooplandbouw speelt (per definitie) op bedrijfsniveau;

- ANLb maatregelen moeten fysiek te controleren zijn (terwijl kringlooplandbouw administratief gecontroleerd wordt);

- maatregelen in de koppeltabel (weinig flexibel) sluiten slecht aan bij kringloop-maatregelen (flexibel, maatwerk)

(Van Rotterdam, Honkoop, van Miltenburg \& Koelemeijer, 2018, p. 5)

\subsection{Invulling van het duurzaamheidspakket}

Er is gezocht naar een systematiek om zowel 'het peloton' te stimuleren als 'de koplopers' te belonen. Waarbij er een principieel verschil is tussen het prikkelen van ondernemers op doelen of via maatregelen. Een keuze tussen die twee kan gemaakt worden op beleidsmatige gronden, maar het kan ook een keuze zijn op grond van draagvlak: sommige agrariërs hebben meer met de flexibiliteit van een doelgerichte benadering, anderen hebben meer met de concreetheid van een maatregelenbenadering.

In de pilot is zowel een doelenpakket als een maatregelenpakket samengesteld. De deelnemers aan de pilot hebben gewerkt met beide pakketten.

Het doelenpakket richt zich op te realiseren doelen, waarbij de te nemen maatregelen om die doelen te bereiken vrij zijn (zie tabel 1). Het puntensysteem in de tabel komt in paragraaf 3.3 aan de orde. 
Tabel 1 Doelenpakket

\begin{tabular}{|c|c|c|c|c|c|c|}
\hline & Doelstelling & Eenheid & 2 & 4 & 6 & Schaalniveau \\
\hline $1 b$ & & $\begin{array}{l}\text { Reductie (kg P2O5/ha) t.o.v. } 3 \\
\text { jarig gemiddelde uit KLW }\end{array}$ & $>-10$ & $>-15$ & $>-20$ & bedrijf \\
\hline $2 a$ & $\mathrm{~N}$-bodemoverschot & Target (kg N/ha) & $\begin{array}{l}\text { veen: }<250 \\
\text { klei: }<125\end{array}$ & $\begin{array}{l}\text { veen }:<225 \\
\text { klei: }<100\end{array}$ & $\begin{array}{l}\text { veen: }<200 \\
\text { Klei: }<75\end{array}$ & bedrijf \\
\hline $2 b$ & & $\begin{array}{l}\text { Reductie (\%) t.o.v. } 3 \text { jarig } \\
\text { gemiddelde uit KLW }\end{array}$ & $>-30 \%$ & $>-50 \%$ & $>-70 \%$ & bedrijf \\
\hline $3 a$ & $\begin{array}{l}\text { NH3-emissie stal- } \\
\text { en mestopslag }\end{array}$ & Target (kg NH3/ GVE) & $<13$ & $<12$ & $<11$ & bedrijf \\
\hline $4 b$ & & $\begin{array}{l}\text { Reductie (kg NH3/ ha) t.o.v. } 3 \\
\text { jarig gemiddelde uit KLW }\end{array}$ & PM & PM & PM & bedrijf \\
\hline 4 & $\begin{array}{l}\text { Overige doelen } \\
\text { (weidevogel en/ of } \\
\mathrm{CO}_{2} \text { reductie) }\end{array}$ & & $\begin{array}{l}\text { OWD + } \\
\text { aangepaste } \\
\text { GWS }\end{array}$ & & & perceel \\
\hline
\end{tabular}

Bij de definiëring van de te behalen doelen was een belangrijke vraag of je zou moeten streven naar absolute doelen of relatieve doelen. Het eerste is het meest interessant voor koplopers, het tweede voor het peloton.

Om het doelenpakket voor beide groepen interessant te maken is daarom een keuzemogelijkheid ingebouwd:

- $\quad$ het behalen van een absoluut doel (interessant voor koplopers).

- het behalen van een relatief doel in de vorm van een reductie t.o.v. het eigen bedrijfsspecifieke 3 jarig gemiddelde (interessant voor peloton).

Het maatregelenpakket richt zich op concrete integrale maatregelen. De maatregelen in tabel 2 zijn geselecteerd op meervoudig winst. Voor onderbouwing van de keuzes zie bijlage 5 . 
Tabel 2 Maatregelenpakket

\begin{tabular}{|c|c|c|c|c|c|c|}
\hline & Maatregel & 1 punt & 2 punten & 3 punten & \multicolumn{2}{|c|}{$\begin{array}{l}\text { Niveau ( } B=\text { bedrijf, } \\
P=\text { perceel }\end{array}$} \\
\hline 1 & Water bij de mest & & & $\begin{array}{l}\text { minimaal } 2 \text { mest: } 1 \\
\text { water }(33 \%)\end{array}$ & B & $\begin{array}{l}\text { Na sleepvoetverbod } \\
1-1-2019 \text { alleen } \\
\text { boven } 33 \% \\
\text { relevant }\end{array}$ \\
\hline 2 & $\begin{array}{l}\text { Uitrijtijd organische } \\
\text { mest }\end{array}$ & $\begin{array}{l}\text { Voorjaar o.b.v. } \\
\text { bodemtemperatuur } \\
\text { min. } 6^{\circ} \mathrm{C} \text { en goede } \\
\text { draagkracht grond, } \\
\text { najaar tot } 15-8\end{array}$ & $\begin{array}{l}\text { Voorjaar o.b.v. bodem- } \\
\text { temperatuur min. } 8^{\circ} \mathrm{C} \text {, } \\
\text { goede draagkracht } \\
\text { grond, en niet meer dan } \\
10 \mathrm{~mm} \text { regen verwacht } \\
\text { binnen } 24 \text { uur (obv } \\
\text { regionale pluim), najaar } \\
\text { tot } 1-8\end{array}$ & & $P$ & $\begin{array}{l}\text { Op basis van } \\
\text { laatste stavaza } \\
\text { kennis. In } 2018 \\
\text { start ook pro-ject } \\
\text { bodem-temper- } \\
\text { atuur afhankelijk } \\
\text { bemesten. }\end{array}$ \\
\hline $3 a$ & $\begin{array}{l}\text { Uitrijtijd } \mathrm{N} \\
\text { kunstmest (klei/ } \\
\text { zand) }\end{array}$ & $\begin{array}{l}\text { Voorjaar: RE module } \\
\text { (Tsom, max benu- } \\
\text { tting), najaar tot 1-9 }\end{array}$ & $\begin{array}{l}\text { Voorjaar: RE module } \\
\text { (Tsom, max benutting), } \\
\text { najaar tot } 15-8\end{array}$ & & $P$ & $\begin{array}{l}\text { Advies: Gebruik } \\
\text { App RE Gras (jara). } \\
\text { Niet toegestaan } \\
\text { tussen } 16 / 9 \text { en } \\
31 / 1\end{array}$ \\
\hline $3 b$ & $\begin{array}{l}\text { Uitrijtijd N } \\
\text { kunstmest (veen) }\end{array}$ & $\begin{array}{l}\text { Voorjaar: RE module } \\
\text { (Tsom, max benut- } \\
\text { ting), najaar tot } 15-8\end{array}$ & $\begin{array}{l}\text { Voorjaar: RE module } \\
\text { (Tsom, max benutting), } \\
\text { najaar tot } 1-8\end{array}$ & & $\mathrm{P}$ & \\
\hline 4 & $\mathrm{~N}$-gift als vaste mest & $\begin{array}{l}5 \% \text { van de maximale } \\
\mathrm{N} \text {-gift uit vaste mest }\end{array}$ & $\begin{array}{l}10 \% \text { van de maximale } \mathrm{N} \text { - } \\
\text { gift uit vaste mest }\end{array}$ & $\begin{array}{l}15 \% \text { van de } \\
\text { maximale } \mathrm{N} \text {-gift uit } \\
\text { vaste mest }\end{array}$ & $\mathrm{B}$ & \\
\hline 5 & Minder N kunstmest & $\begin{array}{l}25 \mathrm{~kg} / \text { ha minder dan } \\
\text { gebruiksnorm }\end{array}$ & $\begin{array}{l}50 \mathrm{~kg} / \text { ha minder dan } \\
\text { gebruiksnorm }\end{array}$ & $\begin{array}{l}75 \mathrm{~kg} / \text { ha minder } \\
\text { dan gebruiksnorm }\end{array}$ & $B$ & \\
\hline 6 & Grasland in beheer & $10 \%$ bedrijfsareaal & & & $\mathrm{B}$ & \\
\hline $7 a$ & $\begin{array}{l}\text { TAN verlagen } \\
\text { (reductie) }\end{array}$ & $\begin{array}{l}\text { TAN - 5/10 kg/ GVE } \\
\text { ten opzichte van } 3- \\
\text { jarig gemiddelde KLW }\end{array}$ & $\begin{array}{l}\text { TAN - 10/15 kg/ GVE ten } \\
\text { opzichte van 3-jarig } \\
\text { gemiddelde uit KLW }\end{array}$ & $\begin{array}{l}\text { TAN - >15 kg/ GVE } \\
\text { ten opzichte van 3- } \\
\text { jarig gemiddelde } \\
\text { KLW }\end{array}$ & $\mathrm{B}$ & \\
\hline $7 b$ & $\begin{array}{l}\text { TAN verlagen } \\
\text { (target) }\end{array}$ & $\begin{array}{l}\text { veen: }<88 \mathrm{~kg} / \mathrm{GVE} \text { of } \\
\text { klei: }<83 \mathrm{~kg} / \mathrm{GVE}\end{array}$ & $\begin{array}{l}\text { veen: }<84 \mathrm{~kg} / \mathrm{GVE} \text { of } \\
\text { klei: }<81 \mathrm{~kg} / \mathrm{GVE}\end{array}$ & $\begin{array}{l}\text { veen: }<81 \mathrm{~kg} / \mathrm{GVE} \\
\text { of klei: }<79 \mathrm{~kg} / \\
\text { GVE }\end{array}$ & $\mathrm{B}$ & \\
\hline 8 & $\begin{array}{l}\text { Beheren } \\
\text { grondwaterpeil met } \\
\text { onderwaterdrainage }\end{array}$ & & $x$ & $\begin{array}{l}\text { inclusief } \\
\text { aangepaste GWS }\end{array}$ & $\mathrm{P}$ & \\
\hline 9 & $\begin{array}{l}\text { Mestvrije zone langs } \\
\text { slootkant }\end{array}$ & $\min .200 \mathrm{~cm}$ & & & $\mathrm{P}$ & \\
\hline 10 & $\begin{array}{l}\text { Langs greppels is } \\
\text { een mestvrije zone }\end{array}$ & & $\begin{array}{l}\min .25 \mathrm{~cm} \text { aan beide } \\
\text { kanten }\end{array}$ & & $\mathrm{P}$ & \\
\hline 11 & $\begin{array}{l}\text { Bagger is met } \\
\text { inachtneming van } \\
\text { hierboven } \\
\text { gespecificeerde } \\
\text { mestvrije zone } \\
\text { opgespoten }\end{array}$ & & $x$ & & $\mathrm{P}$ & \\
\hline 12 & Geen P-kunstmest & & $x$ & & $B$ & $\begin{array}{l}\text { alleen op bedrijven } \\
\text { zonder derogatie }\end{array}$ \\
\hline 13 & P-bodemoverschot & $</=0$ & & & $\mathrm{~B}$ & \\
\hline 14 & $\begin{array}{l}\text { Niet scheuren van } \\
\text { grasland/ geen } \\
\text { gras- } \\
\text { landvernieuwing }\end{array}$ & $>5 \mathrm{jr}$ & $>7 \mathrm{jr}$ & $>10 \mathrm{jr}$ & $\mathrm{P}$ & \\
\hline
\end{tabular}




\subsection{Beloningssystematiek}

$\mathrm{Er}$ is gezocht naar een manier om goed gedrag te belonen. Naar rato van de mate waarin het doel wordt behaald of de zwaarte waarmee de maatregel wordt uitgevoerd, kan de ondernemer punten verdienen (zie tabel 2 en 3 ).

Om de premie te bepalen wordt het totaal aan behaalde punten opgeteld. De premie is gebaseerd op een klasse-verdeling, waarbij men een minimaal aantal punten moet halen om in een bepaalde klasse te vallen. De klasse-verdeling is gebaseerd op (een deel van) het theoretisch maximaal te behalen aantal punten indien alle maatregelen uit het pakket maximaal worden uitgevoerd.

Bij iedere klasse hoort een vergoeding/ ha. Bijvoorbeeld wanneer een deelnemer tussen de 12 en de 16 punten scoort voor de uitgevoerde maatregelen valt hij in klasse 2 en ontvangt hij $€ 35,-/$ ha. Ditzelfde werkwijze kan worden toegepast voor de doelen. In deze pilot zijn de deelnemers uitbetaald op basis van de behaalde punten bij het maatregelenpakket. Vijf deelnemers vielen hierbij in klasse 1 , 4 deelnemers in klasse 2 en 1 deelnemer in klasse 3. Zie tabel 4 en 5.

Tabel 4 Bepaling van de premie/ha.

\begin{tabular}{|c|c|c|c|c|c|}
\hline \multirow[b]{2}{*}{ Klasse } & \multirow[b]{2}{*}{$\begin{array}{l}\text { Fractie van max } \\
\text { punten }\end{array}$} & \multicolumn{2}{|c|}{ Minimaal aantal punten per klasse } & \multicolumn{2}{|c|}{ Bijbehorende premie/ha } \\
\hline & & $\begin{array}{l}\text { Maatregelen - } \\
\text { totaal punten } x \text { ha } \\
\text { / totaal ha }\end{array}$ & Doelen & $\begin{array}{l}\text { Maatregelen } \\
\text { ( }{ } 3,5 / \text { punt) }\end{array}$ & $\begin{array}{l}\text { Doelen } \\
\text { (€2,5/ punt) }\end{array}$ \\
\hline 1 & 0,25 & 8 & 6 & $€ 23$ & $€ 16$ \\
\hline 2 & 0,375 & 12 & 9 & $€ 35$ & $€ 23$ \\
\hline 4 & 0,625 & 19 & 16 & $€ 58$ & $€ 39$ \\
\hline 5 & 0,75 & 23 & 19 & $€ 70$ & $€ 47$ \\
\hline 6 & 0,87 & 27 & 22 & $€ 81$ & $€ 54$ \\
\hline punten & & 31 & 25 & 693 & 663 \\
\hline
\end{tabular}

Tabel 5 Premie per deelnemer.

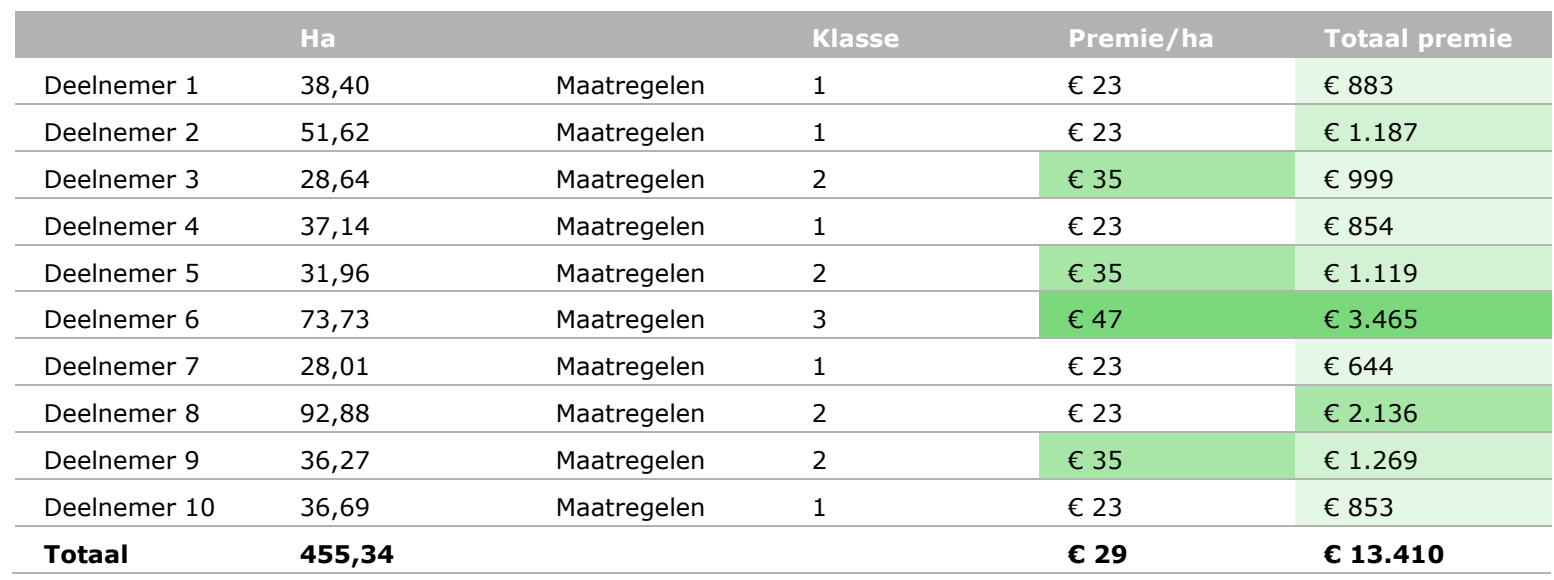

\section{$3.4 \quad$ Monitoring}

In de pilot is gezocht naar mogelijkheden om de maatregelen te borgen. Hierbij is onderscheid gemaakt tussen de monitoring in de pilot zelf en monitoring en borging bij opschaling.

Voor de controle van de uitvoering en het behalen van de verschillende maatregelen en doelen zijn vijf verschillende werkwijzen gehanteerd; via de graslandkalender, via de Kringloopwijzer, met tussentijds 
advies, via fysieke controle en via controle van diverse registraties en contracten die ondernemers hebben. Sommige maatregelen en doelen kunnen het beste worden gecontroleerd door een combinatie van meerdere van deze werkwijzen. In tabel 6 is een samenvatting opgenomen van de gehanteerde werkwijze per maatregel of doel.

Tabel $6 \quad$ Wijze van monitoring van maatregelen of doelen.

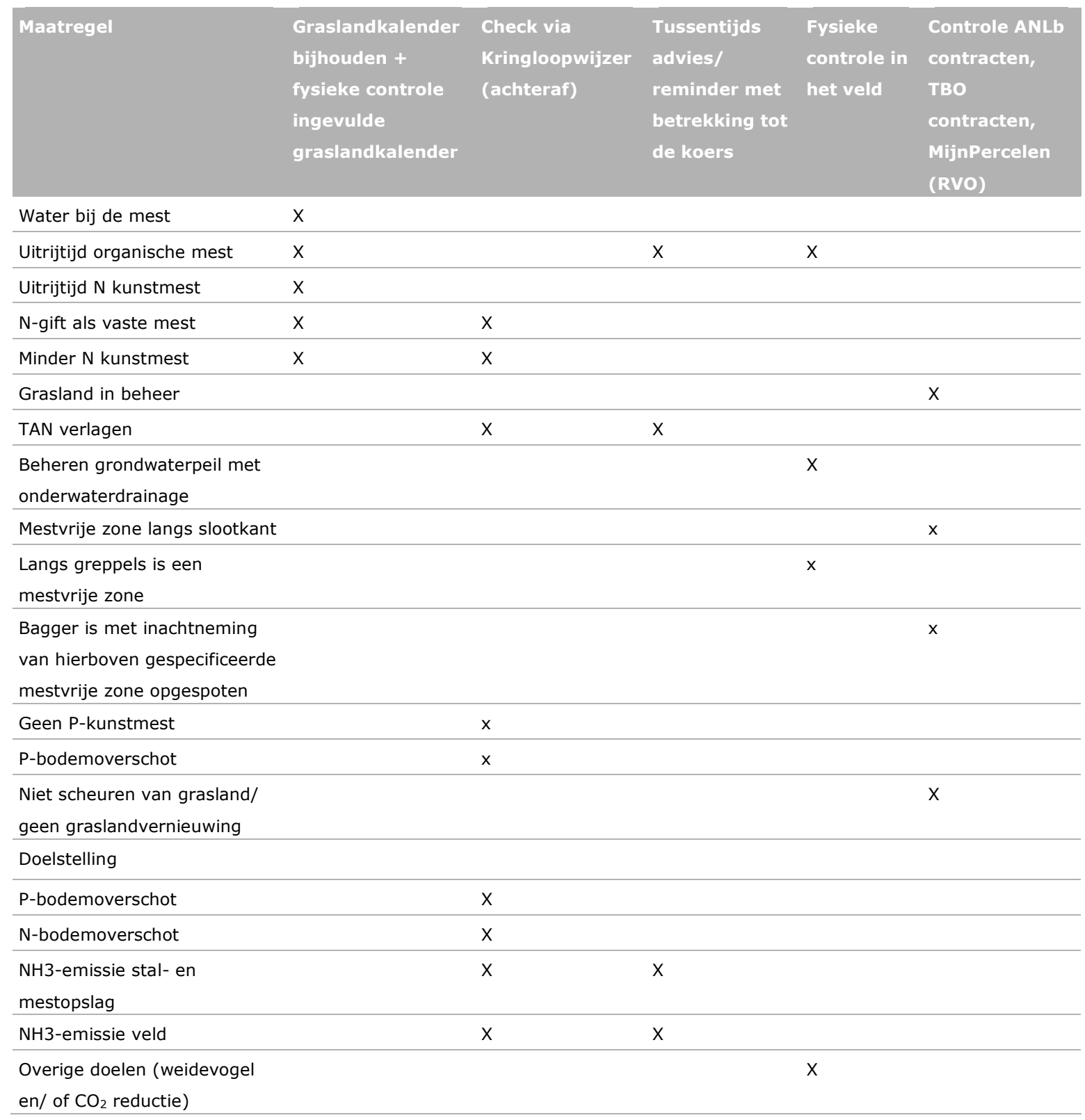

In tabel 7 zijn de werkwijzen vertaald naar meer uitgeschreven acties zoals ondernomen in de pilot en gekoppeld aan een moment. De monitoring in de pilot is uitgevoerd door PPP Agro Advies en LTO Noord. Er zijn drie contactmomenten geweest: eenmaal een persoonlijk keukentafelgesprek bij het afsluiten van het pakket, eenmaal telefonisch om tussentijds de uitvoering te bespreken en afsluitend een keukentafelgesprek in subgroepjes van 3 à 4 deelnemers om de resultaten te bespreken. Na het opstellen van de Kringloopwijzers is in maart 2019 per deelnemer het definitieve aantal punten, en daarmee de te ontvangen premie bepaald.

Uiteraard is dit een werkwijze die past bij een pilot. Bij opschaling is een meer geautomatiseerde vorm van monitoring nodig. Nieuwe technieken, zoals bijvoorbeeld een datalogger (gekoppeld aan GPS en flowmeter/EC meter) op de mesttank, zou de monitoring van maatregelen als de uitrijtijd van mest of water bij de mest eenvoudiger kunnen maken. In Tabel 7 zijn voorstellen opgenomen voor monitoring van de beschreven maatregelen en doelen bij opschaling. 
Tabel 7 Monitoringplan pilot Duurzaamheidspakketten.

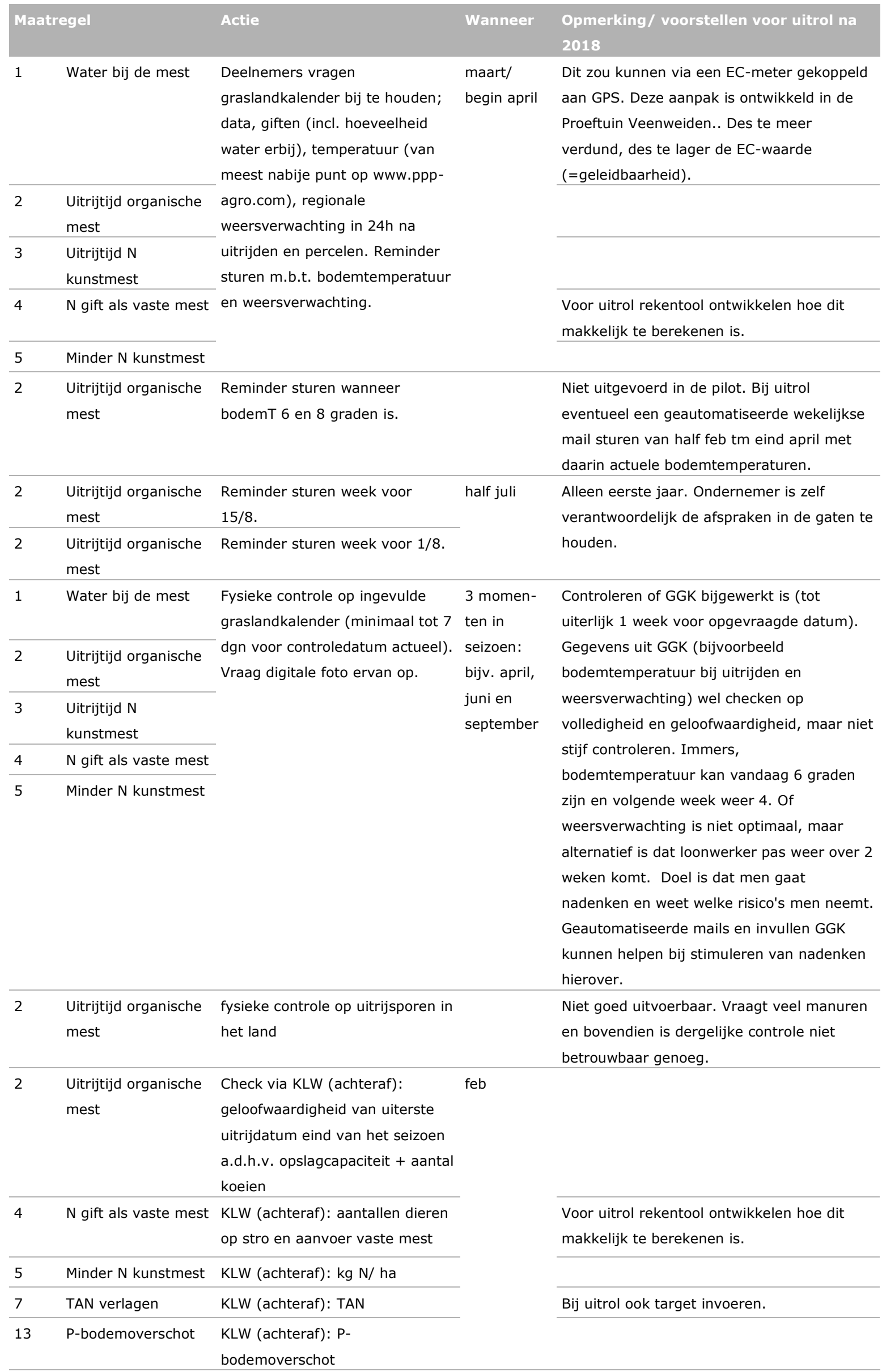




\begin{tabular}{|c|c|c|c|c|}
\hline \multicolumn{2}{|c|}{ Maatregel } & \multirow{2}{*}{$\begin{array}{l}\text { Actie } \\
\text { Controle via ANLb contracten en } \\
\text { TBO contracten }\end{array}$} & \multirow[t]{2}{*}{ Wanneer } & \multirow{2}{*}{$\begin{array}{l}\text { Opmerking/ voorstellen voor uitrol na } \\
2018 \\
\text { Niet in de pilot. Bij uitrol de ondernemer } \\
\text { vragen om bij afsluiten van } \\
\text { duurzaamheidspakket ANLb contracten en } \\
\text { TBO contracten te overleggen. Eventueel } \\
\text { ANLb contract wat gedurende jaar wijzigt } \\
\text { achteraf aanvullen. }\end{array}$} \\
\hline 6 & Beheergronden & & & \\
\hline 7 & TAN verlagen & $\begin{array}{l}\text { Tussentijds advies of men de } \\
\text { juiste koers te pakken heeft op } \\
\text { basis van ureumgehalte }\end{array}$ & $\begin{array}{l}\text { juni/ juli (na } \\
\text { eerste snee) }\end{array}$ & $\begin{array}{l}\text { Alleen eerste jaar. Ondernemer is zelf } \\
\text { verantwoordelijk de afspraken in de gaten te } \\
\text { houden. }\end{array}$ \\
\hline 8 & Onderwaterdrainage & Fysieke controle in het veld & & $\begin{array}{l}\text { Niet in de pilot. Bij uitrol mogelijk ten dele } \\
\text { via waterschap en ten dele via fysieke } \\
\text { controle }\end{array}$ \\
\hline 9 & $\begin{array}{l}\text { Mestvrije zone langs } \\
\text { slootkanten }\end{array}$ & & & $\begin{array}{l}\text { Theoretisch kan een ondernemer ook zone } \\
\text { aanhouden zonder dit afgesproken te } \\
\text { hebben via een ANLb pakket, maar omdat } \\
\text { deze maatregelen zoveel lijken op pakket } \\
\text { 'Weideranden' werkt het verwarrend. In } \\
\text { deze pilot is } 100 \% \text { van de opgegeven }\end{array}$ \\
\hline 11 & $\begin{array}{l}\text { Bagger opgespoten } \\
\text { met in acht neming } \\
\text { mestvrije zone }\end{array}$ & & & $\begin{array}{l}\text { punten hiervoor al beloond via ANLb. Als je } \\
\text { deze er bij uitrol uit moet filteren wordt het } \\
\text { ingewikkeld. Suggestie is om deze } \\
\text { maatregelen bij uitrol niet op te nemen in } \\
\text { duurzaamheidspakket. Anders bij uitrol per } \\
\text { m1 ipv per ha. }\end{array}$ \\
\hline 14 & $\begin{array}{l}\text { Geen } \\
\text { graslandvernieuwing }\end{array}$ & $\begin{array}{l}\text { Check meldingen en MijnPercelen } \\
\text { RVO }\end{array}$ & & $\begin{array}{l}\text { Niet in de pilot. Bij uitrol moet veehouder } \\
\text { gecombineerde opgave (MijnPercelen) } \\
\text { doorgeven bij afsluiten contract. }\end{array}$ \\
\hline
\end{tabular}




\section{$4 \quad$ Conclusies en aanbevelingen}

\subsection{Conclusies}

Welke prikkel gaat er uit van het duurzaamheidspakket?

De primaire vraag van de pilot is of de deelnemers door introductie van het duurzaamheidspakket en premie geneigd zijn andere managementbeslissingen te nemen en daarmee duurzamer te gaan werken.

Een pilot over 1 jaar levert dan per definitie slechts een indicatie op hoe een en ander zou kunnen werken. Door de extreme droogte in 2018 is dit in dit geval nog lastiger. Twee voorbeelden:

- Geen enkele deelnemer heeft de ambitie kunnen waarmaken om na 15 augustus geen organische mest meer uit te rijden, omdat het voor 15 augustus simpelweg te droog was om te kunnen uitrijden.

- Ook de behaalde resultaten in termen van veld- en stalemissies en TAN productie bleven achter, zowel ten opzichte van het eigen meerjarig gemiddelde als ten opzichte van het meerjarig gemiddelde van een benchmark groep van 228 ondernemers (zie bijlage 4).

Niettemin valt er lering te trekken uit de ervaringen van deelnemers, met name met betrekking tot de systematiek en de definiëring van maatregelen en doelen.

\section{Ervaringen van deelnemers}

De belangrijkste ervaringen zijn:

- Voor sommige maatregelen zijn ondernemers zeker geneigd om andere afwegingen te maken. Dit betreft vooral de uitrijtijd van kunstmest, de hoeveelheid kunstmest en de TAN (of ureum of RE gehalte).

- Voor andere maatregelen is de drempel voor de benodigde verandering (nog) te groot. Zo kost een verdunning van $1: 1$ water bij de mest (te)veel extra tijd van de loonwerker en is $1: 1$ verdunnen bij zelf uitrijden vaak niet haalbaar.

- $\quad$ Een andere, meer indirecte prikkel die wordt ervaren is dat de 'sport-beleving' rond kringlooplandbouw wordt gestimuleerd. Dat heeft zo gewerkt rond het weidevogelbeheer, het zou ook kunnen werken rond kringlooplandbouw. De vergoeding geeft ondernemers het gevoel dat hun inspanning gewaardeerd wordt. .

- Daarnaast is men van mening dat de sector hard toe is aan positieve stimulansen. Veel agrariërs voelen zich momenteel negatief bejegend vanuit de vele complexe regels en ze ervaren controledrang. Men heeft het gevoel dat de ondernemersvrijheid wordt ingeperkt en dat alle maatschappelijke problemen (water-kwaliteit, stikstofdepositie, klimaatverandering, etc.) worden toegeschreven aan de sector. Het pakket kan daar tegenwicht aan geven.

In bijlage 2 en 3 zijn de andere ervaringen en adviezen van de deelnemers opgenomen.

\subsection{Aanbevelingen}

Inzetbaarheid/ wenkend perspectief van de pakketten-aanpak

De uitkomsten van de pilot Duurzaamheidspakketten zouden in de toekomst als input kunnen gaan dienen voor een aantal denkbare sporen om de genoemde maatschappelijke doelen te bereiken;

- Regionale uitrol via het ANLb, inclusief een kenniscomponent, met ruimte voor de boer als sparringpartner voor maatwerk.

- Brede uitrol via het GLB. Dit kan een interessant spoor zijn om het 'peloton' te bereiken.

- Voor specifieke gebieden met specifieke opgaven. Bijvoorbeeld als een waterschap in een deelstroom-gebied waterkwaliteitsproblemen wil oplossen of als een provincie nabij een N2000 gebied de depositie van ammoniak wil beperken. Hierbij gaat het om regionaal maatwerk gekoppeld aan specifieke doelstellingen voor een bepaald gebied 
Steeds is de vraag daarbij van belang welke partij(en) een potentieel probleem hebben en daarmee (mede)probleemhouder zijn.

Focus op meest kansrijke maatregelen

Een van de conclusies uit de pilot was dat sturing op maatregelen eerder een prikkel vormen voor ondernemers dan sturing op doelen. Niettemin werden de 14 maatregelen door de deelnemers als omvangrijk ervaren. Bij toekomstige inzet van een dergelijk pakket adviseren zij om te focussen op de 5-6 meest effectieve maatregelen. Voor een zo breed mogelijk maatschappelijk effect en tegelijkertijd een zo breed mogelijk draagvlak onder agrariërs, zouden dat de volgende maatregelen kunnen zijn:

- De mest 1:1 met water verdunnen (borging via volume meter of EC-meter i.c.m. een datalogger)

- Een (gemiddeld $10 \%$ ) lagere TAN (borging via KLW)

- Gemiddeld 500 uur meer weidegang (borging via $\mathrm{CO} 2$ meter in de stal)

- Minder kunstmest en het niet te laat uitrijden van kunstmest

- Sturen van grondwaterpeil met behulp van onderwaterdrainage

- Netjes \& op juiste moment uitrijden

Overige aanbevelingen

Vanuit de bevindingen van de pilot en de samenwerking met de Pilot Kringlooppakket (van Rotterdam et al, 2019) zijn nog enkele aanbevelingen te formuleren:

- Creëer een kleine instapdrempel om de drive gedurende het seizoen te vergroten. Dit kan bijvoorbeeld door een inlegpremie te vragen aan deelnemers, gebaseerd op de omvang van het bedrijf: bijvoorbeeld $<30 \mathrm{ha}=€ 250,-, 30-60$ ha $=€ 500$,- en $>60$ ha $=€ 750,-$. De inlegpremie wordt alleen terugverdiend bij het halen van een minimaal aantal punten. Mogelijk nadeel hiervan is dat ondernemers niet meer willen instappen. Een alternatief kan zijn om bij deelname sommige maatregelen verplicht te stellen.

- Communiceer over waarom je wat en wanneer doet.

- Bij diverse maatregelen zijn specifieke afwegingen te maken. Deze zijn terug te vinden in bijlage 2 en 3. 


\section{Bronnen}

Evers A., M. de Haan, G. Migchels, L. Joosten, M. van Leeuwen. 2019. Effecten van ammoniakreducerende maatregelen in bedrijfsverband. Scenariostudie voor proeftuin Natura 2000 in veenweidegebied. Wageningen Livestock Research, ORG-ID, Projecten LTO Noord. WUR-rapport 1161.

Migchels, G, van Leeuwen, M., Joosten L., (2019) Verkenning keten- en gebiedsgerichte aanpak. Wageningen Livestock Research, Projecten LTO Noord,. ORG-ID.

Van Rotterdam, D., Honkoop, W., van Miltenburg, J. \& Koelemeijer A. (2018) Pilot kringlooppakket, ontwikkeling pakket en toetsing in de praktijk. Nutrienten Management Instituut, PPP-Agro Advies, Agrarisch collectief Rijn, Vecht en Venen, Agrarisch collectief Water, Land en dijken. 


\section{Bijlage 1 Deelnemerslijst pilot}

\begin{tabular}{ll} 
Naam & Woonplaats \\
\hline Marja Dijkshoorn & Nieuwerbrug \\
\hline Martin van der Hoeven & Driebruggen \\
\hline Machiel Karens & Nieuwerbrug \\
\hline Gert de Koning & Nieuwerbrug \\
\hline Sjaak de Roos & Waarder \\
\hline Mieke Vergeer & Bodegraven \\
\hline Dirk Verlaan & Waarder \\
\hline Anton de Wit & Reeuwijk \\
\hline Adriaan Zwanenburg & Waarder \\
\hline Bartlo Hoogendijk & Driebruggen \\
\hline
\end{tabular}




\section{Bijlage 2 Vragen en aanbevelingen n.a.v. gesprek met deelnemers}

Algemeen

- 14 maatregelen is nog vrij veel. Inkrimpen naar 3 - 5 maatregelen.

- Het is nu wel heel vrijblijvend. Suggestie: startpremie vragen om zeker te weten dat men ambitie serieus neemt. Bij uitrol inlegpremie vragen aan deelnemers, gebaseerd op omvang bedrijf: bijvoorbeeld $<30$ ha $=€ 250,-, 30-60$ ha $=€ 500$,- en $>60$ ha $=€ 750,-$. Je krijgt je inlegpremie alleen terug wanneer je minimaal $75 \%$ van je punten haalt. Evt. nog vast bedrag er bovenop om uitvoering te financieren (controles door partij $x$ ).

- Vinden we graslandkalender een goed middel om e.e.a. mee te borgen/ registreren?

- Bemestingsapp is te veel gericht op NH3. App kleurt onder de 6 graden groen bij weinig wind en zon, terwijl uitrijden dan slecht is voor de waterkwaliteit.

- Minder N kunstmest kunnen kiezen per ha: bijvoorbeeld voor x ha 1 punt en voor $\mathrm{x}$ ha 3 punten.

- Veen/klei verhouding doorrekenen in puntentoekenning

- Het is lastig voor de deelnemers om aan het begin van het jaar te kiezen tussen doelen en maatregelen. Aanbeveling: voorkom zo'n 'keuze vooraf'. Ofwel alleen maatregelen, dan wel maatregelen en doelen i en ondernemer achteraf laten kiezen. Uiteraard zal dat laatste leiden tot de afweging 'wat levert de hoogste premie op?'. Dit lijkt echter geen schade te doen aan het doel: boeren uitdagen hun bedrijfsvoering te verduurzamen.

Water bij de mest

- Geldt de norm 1:2 gemiddeld over het jaar? Bijv: voorjaar 10\%, zomer 50\%.

- Misschien is het eerlijker om te belonen over \% van je mest of in m3 mest in plaats van per ha. Als je geen mest uitrijdt op bijv. SBB land, dan heb je minder ha's maar wel $100 \%$ van je mest.

Uitrijtijd organische mest

- Vraag: Gaat een najaarsdatum uitrijden van $15 / 8$ is niet een te hoge drempel opwerpen?

- Vraag: Bij sommige ondernemers is de mestput (nog) niet groot genoeg. Extra mestopslag is een dure maatregel

- Vraag: Schuim op de mest komt soms de put uit. Wat is de oorzaak?

Uitrijtijd $N$ kunstmest (klei/ zand)

- Vraag: Ondernemers willen soms laat kunstmest uitrijden tegen schimmels in het gras. Is dit nodig/ effectief?

- Najaarsdatum staat voor klei/ zand op 1/9 (1 punt) en 15/8 (2 punten). Bij uitrol naar veen kan dit naar $15 / 8$ en $1 / 8$ (volgens model NMI/ PPP?)

- Het voorjaar staat nu op RE module (Tsom, max benutting), maar dat is geen issue. Niet noodzakelijk benoemen.

Grasland in beheer

- Vraag: Het gaat hier om een zwaardere eerste snede = lager RE gehalte = lagere ammoniakuitstoot en dalende bodemoverschotten (alhoewel bij intensieve bedrijven het argument van de ammoniakuitstoot niet opgaat omdat mais vervangen wordt door gras). Voorstel: natuurgronden (particulier en SBB) en zwaardere ANLb pakketten; botanisch beheer en weidevogelpakketten met uitgestelde maaidatum tot ??

- Wat wordt hieronder verstaan? Nader toelichten (ook term beheerland uit KLW voor veel boeren niet duidelijk). Bijvoorbeeld natuurgrond en agrarische grond met pakketten met uitgestelde maaidatum: 1 a t/m 1t, $2 \mathrm{a} \mathrm{t} / \mathrm{m}$ 2e (??), 4d t/m 4h (??), $5 \mathrm{a} \mathrm{t/m} \mathrm{5g,13e} \mathrm{t/m} \mathrm{13g} \mathrm{(??).}$

TAN verlagen (reductie)

- Vraag; Hebben boeren met ambitie om in ureum te zakken, ook automatisch ambitie op de TAN?. 
- Vraag: TAN of Ureum? Ureum is heel praktisch. Weet je iedere 3 dagen en daar kun je op sturen. Maar ureaum houdt geen rekening met hoeveelheid jongvee. TAN wel.

- Ook bij deze maatregel een target invoeren.

Beheren grondwaterpeil met onderwaterdrainage

- Deel van boeren uit deze pilot zit in polder Lange Weiden, waar grootschalige uitrol van OWD op de planning staat. Door droge zomer 2018 nog niet uitgevoerd.

- Veel van deze boeren zijn van plan om voorlopig onderwaterdrainage zonder pompputten aan te leggen.

Mestvrije zone langs slootkant (min. $2 m$ )

- Veel deelnemers leggen de link met 'pakket weiderand' uit ANLb. Maar is de eis daar ook $2 \mathrm{~m}$ ?? Goed om de maatregelen nog een keer naast de eisen uit de ANLb pakketten leggen.

- Ook als de eis van $2 \mathrm{~m}$ extra is t.o.v. het ANLb pakket, is de vraag of je dit moet willen. Leidt tot verwarring.

- Het werk dat een deelnemer eraan heeft is afhankelijk van de perceelsomvang. Advies: werken in $\mathrm{m} 2 \mathrm{ipv}$ in ha.

Bagger is met inachtneming van hierboven gespecificeerde mestvrije zone opgespoten

- Vraag: Is dit niet ook al een onderdeel van het ANLb pakket?

- Bagger is waardevol product, maar je brengt het op met warm weer. Zowel het veen vervluchtigd (waardevol ophoogmateriaal) als de $\mathrm{N}$.

- Alleen voor ha's waarvoor 9 ook geldt.

P-bodemoverschot

- P monsters zijn fraudegevoelig. Ga uit van forfaitaire normen. Door niet representatieve monsters uit voorgaande jaren kan er op papier $\mathrm{P}$ in de put blijven zitten, wat er in het echt niet inzit. 


\section{Bijlage 3 Analyse met deelnemers pilot Pakketten}

(november/december 2018)

\section{Suggesties/ kanttekeningen bij pakket in het algemeen}

- De tastbaarheid van een maatregel is van groot belang voor effectiviteit. Dat wil zeggen; alleen wanneer een boer een maatregel kan zien, of regelmatig waardes doorkrijgt die indiceren of de maatregel goed is uitgevoerd, zal hij er op gaan sturen. Een voorbeeld hiervan is kiezen voor < 160 RE (170 in de zomer) of ureumgehalte in plaats van TAN (zie onderstaand bij maatregel 7: TAN verlagen).

- Een aantal deelnemers voelen sterke weerstand tegen introductie van een datalogger die vastlegt wanneer welke mest wordt uitgereden. Hetzelfde geldt (in mindere mate) voor een $\mathrm{CO} 2$ meter in de stal. De overtuiging leeft dat dit vooral zal worden gebruikt om met terugwerkende kracht te (kunnen) zoeken naar 'fouten', om zo ook met terugwerkende kracht boetes te kunnen opleggen. Afspraken dat informatie gewist wordt na een $x$ periode, worden niet vertrouwd. Digitale gegevens verdwijnen nooit helemaal.

- $\quad$ Andere deelnemers zien daarentegen in de datalogger een goed middel om te borgen dat beloond kan worden wat je goed doet.

- De zuivelindustrie gaat werken met 3 jarige gemiddelden. Deze periode is te kort om extremen zoals het seizoen 2018 af te vlakken. Beter zou zijn om te gaan werken met 5 jarige gemiddelden.

- De zuivelindustrie drukt prestaties doorgaans uit per liter melk, niet per hectare. Dat is begrijpelijk aangezien het aansluit op het product van de industrie, maar het leidt niet altijd tot de gewenste ontwikkeling. Verschillende duurzame, grondgebonden en extensieve bedrijven scoren bijvoorbeeld niet voldoende op de klimaatmodule van Foqus Planet van Friesland Campina. Voor een intensief bedrijf en/ of bedrijven die veel mais voeren is het gemakkelijker hierop te scoren. Daarnaast is het rekenkundig ook zo dat opstallers makkelijker scoren op de klimaatmodule. In de praktijk is dit echter opgelost doordat opstallers uitgesloten zijn van deelname aan Foqus Planet.

- SBB land niet meenemen in bedrijfsareaal. Dit is land waar je in feite niets doet, dus het pakket genereert ook geen verbetering door dit mee te nemen.

\section{Suggesties/ kanttekeningen bij specifieke maatregelen}

\section{Maatregel 1: Water bij de mest}

- Water bij de mest is zowel bedrijfseconomisch als wat betreft NH3 emissie een goede maatregel, mits tegelijkertijd minder kunstmest wordt toegepast. Zo niet, zal water bij de mest ertoe leiden dat het bodemoverschot omhoog gaat.

- $\quad 1: 1$ verdunnen kost ongeveer $€ 0,70 / \mathrm{m} 3$ meer dan 1:2 verdunnen, maar levert normaal gesproken meer groei op met minder kunstmest. Met een eigen mestrijder is $1: 1$ verdunnen niet haalbaar. De meningen lopen uiteen of $1: 1$ verdunnen door de loonwerker wel haalbaar is.

- $\quad 1: 1$ verdunnen is vooral zinvol voor de mestgift na $1 / 6$. Bijkomend voordeel is dat loonwerkers in de drukste tijd dan geen extra tijd kwijt zijn door $1: 1$ te verdunnen.

- Wanneer een EC meter als borgingsinstrument voor verdunning van de mest wordt gehanteerd, wordt feitelijk het zoutgehalte gemeten. Vraag: Wat voor invloed heeft het wanneer je bijvoorbeeld natronloog voert aan de koeien? Antwoord: Zout zou in de melk terecht moeten komen en zodoende niet leiden tot een zoutere mest.

- Vraag: moet bemesten met de zodenbemester ook niet beloond worden als je ook verdund uitrijden beloont? Antwoord: nee, NH3 emissie van een zodenbemester staat gelijk aan 1:2 verdund uitrijden. Beide zijn niet bovenwettelijk en horen daarmee ook niet thuis in een pakkettensysteem.

\section{Maatregel 3: Uitrijtijd kunstmest}

- De 3 ondernemers uit groep 1 hebben in de 2e helft van augustus nog (heel dun) kunstmest uitgereden. Dit om te zorgen dat de silo leeg was, zodat het restant niet vast gaat zitten. De 
ondernemers uit groep 2 zagen dit niet als een risico en hebben allen het restant in de silo laten zitten voor seizoen 2019.

- $\quad$ Bij minder N Kunstmest kan het criterium van $25 \mathrm{~kg} /$ ha minder dan de gebruiksnorm vervallen. Dit is te vanzelfsprekend gebleken en niet ambitieus genoeg om in deze vorm beloond te worden.

Maatregel 4: N-gift als vaste mest

- Omdat het buiten de meststoffenwet valt wordt het aandeel gecomposteerd slootkantenmaaisel niet meegenomen in deze maatregel. Terecht?

- $\quad$ Ervaring van een van de deelnemers met gecomposteerd slootkantenmaaisel in droog jaar 2018 is dat precies aan de grasgroei te zien was waar gestrooid was. Het OS gehalte van de grond was daarvoor ook al hoog dus dit lijkt een indicatie dat zelfs bij een relatief hoog OS gehalte, compost nog bijdraagt aan het vasthouden van water in de bodem. De betreffende deelnemer had in 2018 (naar verwachting) niet veel minder grasopbrengst dan andere jaren.

Maatregel 6: Grasland in beheer

- Wanneer SBB gronden niet meer meegenomen worden gaat de maatregel Grasland in beheer alleen nog over grasland met zwaardere pakketten van ANLb (uitgestelde maaidatum + plas-dras) erop.

\section{Maatregel 7: TAN verlagen}

- Wanneer je TAN als maatregel hanteert, moet je daar ook de keuze tussen target (voor koplopers) of reductie (voor peloton) hanteren.

- $\quad$ Agrariërs hebben nog weinig hoogtegevoel bij het begrip TAN. Daarnaast weet je pas achteraf, bij het invullen van de KLW wat de TAN van afgelopen jaar was. Dat maakt het lastig om op te sturen. Is het, om aan te sluiten bij de handelswijze van de agrariër daarom niet handiger om te kiezen voor < 160 RE (170 in de zomer) of ureumgehalte in plaats van TAN? TAN is het meest zuiver. Nadeel van RE in rantsoen is dat het verschil tussen het berekende RE en het werkelijke RE in het rantsoen soms vrij groot is. Het nadeel van het ureumgehalte is dat geen rekening wordt gehouden met de hoeveelheid jongvee. Bij TAN wel. Mogelijke compromis is afrekenen op TAN, maar tussentijds sturen aan de hand van RE en ureumgehalte.

- Mestvrije zones langs greppels. Mest in de greppel mag sowieso al niet, tenzij de greppel droog ligt. 


\section{Bijlage $4 \mathrm{NH}_{3}$ prestaties Pilot Duurzaamheidspakketten}

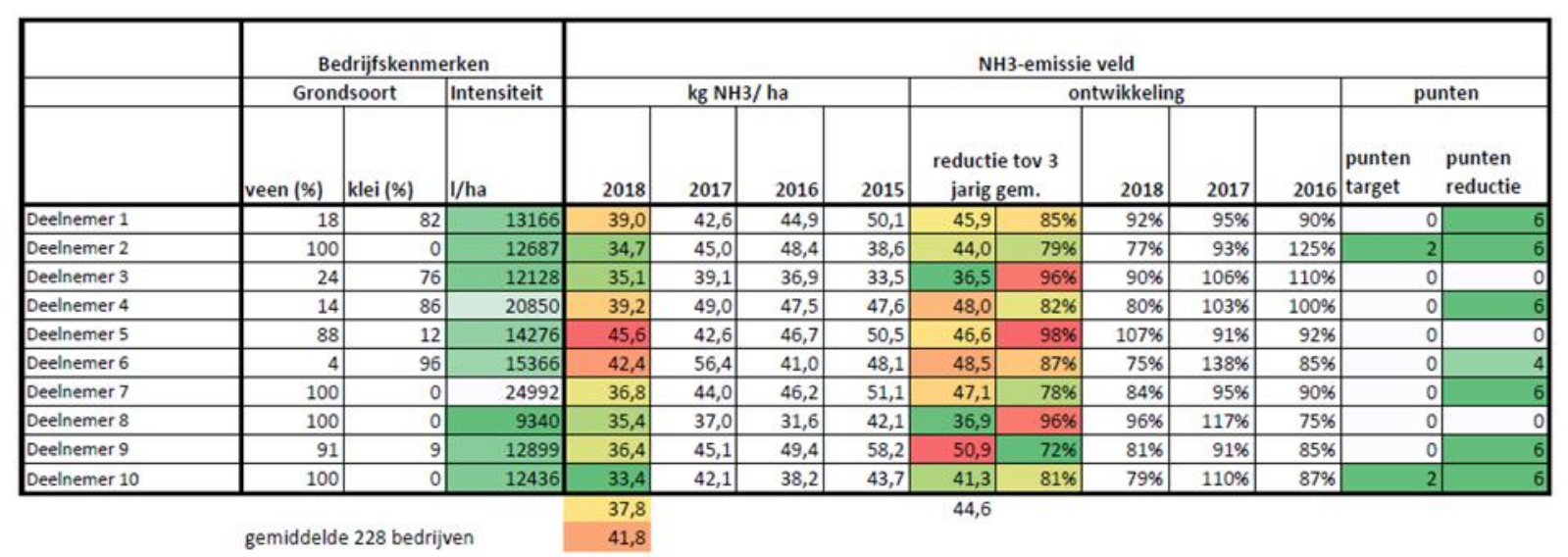

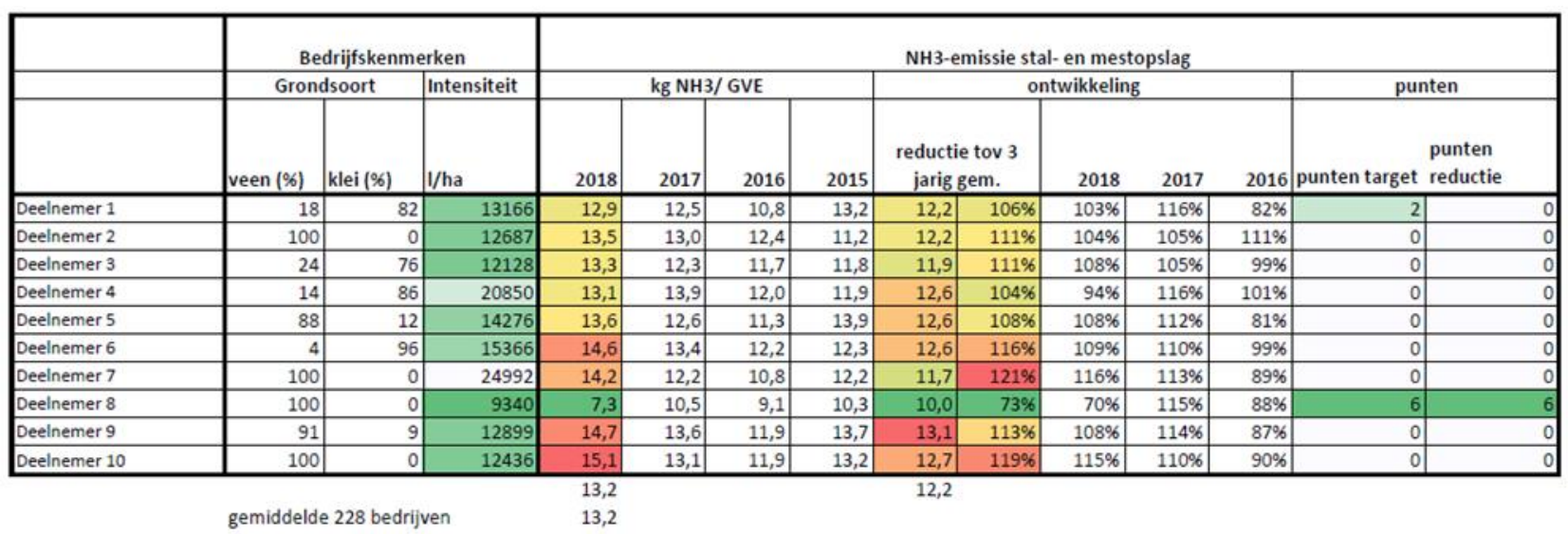

\begin{tabular}{|c|c|c|c|c|c|c|c|c|c|c|c|c|c|}
\hline & \multicolumn{3}{|c|}{ Bedrijfskenmerken } & \multicolumn{10}{|c|}{ TAN productie, excl. staldieren } \\
\hline & \multicolumn{2}{|c|}{ Grondsoort } & \multirow{2}{*}{\begin{tabular}{|l|} 
Intensiteit \\
/ha
\end{tabular}} & \multicolumn{4}{|c|}{ kg NH3/ GVE } & \multicolumn{4}{|c|}{ ontwikkeling } & \multicolumn{2}{|c|}{ punten } \\
\hline & veen (\%) & klei (\%) & & 2018 & 2017 & 2016 & 2015 & $\begin{array}{c}\text { reductie } \\
\text { jarig }\end{array}$ & tov 2 & 2018 & 2017 & $\begin{array}{l}\text { punten } \\
\text { target }\end{array}$ & $\begin{array}{l}\text { punten } \\
\text { reductie }\end{array}$ \\
\hline Deelnemer 1 & 18 & 82 & 13166 & 77,3 & 77,8 & 81,4 ? & ? & 79,6 & $-2,3$ & $99 \%$ & $96 \%$ & 3 & 0 \\
\hline Deelnemer 2 & 100 & 0 & 12687 & 84,8 & 78,3 & 92,4 ? & ? & 85,4 & $-0,5$ & $108 \%$ & $85 \%$ & 1 & 0 \\
\hline Deelnemer 3 & 24 & 76 & 12128 & 87,7 & 83,5 & 91,3 ? & ? & 87,4 & 0,3 & $105 \%$ & $91 \%$ & 0 & 0 \\
\hline Deelnemer 4 & 14 & 86 & 20850 & 77,8 & 81,6 & 85,6 ? & ? & 83,6 & $-5,8$ & $95 \%$ & $95 \%$ & 3 & 1 \\
\hline Deelnemer 5 & 88 & 12 & 14276 & 83,4 & 79,6 & 84,4 ? & ? & 82,0 & 1,4 & $105 \%$ & $94 \%$ & 1 & 0 \\
\hline Deelnemer 6 & 4 & 96 & 15366 & 86,6 & 83,0 & 94,0 ? & ? & 88,5 & $-1,9$ & $104 \%$ & $88 \%$ & 0 & 0 \\
\hline Deelnemer 7 & 100 & 0 & 24992 & 92,8 & 83,8 & 78,0 ? & ? & 80,9 & 11,9 & $111 \%$ & $107 \%$ & 0 & 0 \\
\hline Deelnemer 8 & 100 & 0 & 9340 & 80,6 & 79,3 & 82,5 ? & ? & 80,9 & $-0,3$ & $102 \%$ & $96 \%$ & 3 & 0 \\
\hline Deelnemer 9 & 91 & 9 & 12899 & 95,3 & 96,8 & 98,7]? & ? & 97,8 & $-2,5$ & $98 \%$ & $98 \%$ & 0 & 0 \\
\hline Deelnemer 10 & 100 & 0 & 12436 & 94,3 & 85,8 & 89,9 ? & ? & 87,9 & 6,5 & $110 \%$ & $95 \%$ & 0 & 0 \\
\hline
\end{tabular}

\begin{tabular}{|c|c|c|c|c|c|}
\hline & \multicolumn{3}{|c|}{ Bedrijfskenmerken } & \multirow{3}{*}{$\begin{array}{l}\text { Premie- } \\
\text { klasse }\end{array}$} & \multirow[b]{3}{*}{ Vergoeding } \\
\hline & \multicolumn{2}{|c|}{ Grondsoort } & \multirow{2}{*}{$\begin{array}{l}\text { Intensiteit } \\
\text { I/ha }\end{array}$} & & \\
\hline & veen (\%) & klei (\%) & & & \\
\hline Deelnemer 1 & 18 & 82 & 13166 & 2 & $€ 2.136$ \\
\hline Deelnemer 2 & 100 & 0 & 12687 & 1 & $€ 1.187$ \\
\hline Deelnemer 3 & 24 & 76 & 12128 & 1 & $€ 853$ \\
\hline Deelnemer 4 & 14 & 86 & 20850 & 2 & $€ 999$ \\
\hline Deelnemer 5 & 88 & 12 & 14276 & 2 & $€ 1.119$ \\
\hline Deelnemer 6 & 4 & 96 & 15366 & 1 & $€ 854$ \\
\hline Deelnemer 7 & 100 & 0 & 24992 & 1 & $€ 644$ \\
\hline Deelnemer 8 & 100 & 0 & 9340 & 3 & $€ 3.465$ \\
\hline Deelnemer 9 & 91 & 9 & 12899 & 2 & $€ 1.269$ \\
\hline Deelnemer 10 & 100 & 0 & 12436 & 1 & $\epsilon 883$ \\
\hline
\end{tabular}




\section{Bijlage 5 Selectie van maatregelen voor het duurzaamheidspakket}

Op basis van effectiviteit, integraliteit en borgbaarheid zijn onderstaande maatregelen geselecteerd voor het duurzaamheidspakket:

1. Verlagen TAN

- Minder kunstmest, scoort ook goed op waterkwaliteit, $\mathrm{CO} 2$ en biodiversiteit

- Grasland in beheer, scoort ook goed op biodiversiteit

- Onderwaterdrainage, scoort ook goed op waterkwaliteit, $\mathrm{CO} 2$ en bodemdaling

2. Verdunnen mest

3. Maatregelen, primair gericht op waterkwaliteit:

- Uitrijtijd drijf- en kunstmest

- $\quad \mathrm{N}$ gift als vaste mest

- Mest- en baggervrije zones langs sloot en greppel

- Geen P kunstmest (alleen voor bedrijven die geen gebruik maken van derogatie)

- Geen P bodemoverschot

- Niet scheuren van grasland/ geen graslandvernieuwing

Bij de selectie zijn diverse afwegingen en keuzes gemaakt.

Er is vooral gezocht naar maatregelen die integrale winst opleveren (zie de tabel):

- Minder RE in het krachtvoer, minder eiwitrijk ruwvoer, later maaien en eiwitarm bijproduct voeren zijn maatregelen die bijdragen aan het verlagen van de TAN. Bovendien is het relatief arbeidsintensief om al deze sporen apart te monitoren en te borgen. Deze maatregelen zijn daarom niet als aparte maatregel opgenomen in het pakket maar geclusterd onder de maatregel 'verlagen TAN'.

- De reden dat minder kunstmest, grasland in beheer en onderwaterdrainage (ook maatregelen die leiden tot een lagere TAN) wel als aparte maatregel zijn meegenomen is hun integrale karakter. Deze maat-regelen scoren ook goed op waterkwaliteit, $\mathrm{CO} 2$, bodemdaling en/ of biodiversiteit.

\begin{tabular}{|c|c|c|c|c|c|c|}
\hline & NH3 & $\begin{array}{c}\text { Water- } \\
\text { kwaliteit }\end{array}$ & $\mathrm{CO2}$ & $\begin{array}{l}\text { Biodiver } \\
\text { siteit }\end{array}$ & $\begin{array}{l}\text { Bodem- } \\
\text { daling }\end{array}$ & $\begin{array}{c}\text { Econo } \\
\text { mie }\end{array}$ \\
\hline Later maaien & $+/ 0$ & + & $+/-$ & ++ & 0 & ++ \\
\hline Minder kunstmest & ++ & ++ & ++ & ++ & 0 & $-/+$ \\
\hline Minder RE krachtvoer & + & + & + & $+/ 0$ & 0 & + \\
\hline Eiwitarm bijproduct & + & + & + & + & 0 & + \\
\hline Grasland in beheer & + & + & 0 & ++ & 0 & + \\
\hline Meer weiden & $+/++$ & -- & - & + & 0 & $+/--$ \\
\hline Mest verdunnen & +++ & ++ & 0 & + & 0 & +++ \\
\hline Onderwaterdrainage & + & +++ & ++ & 0 & +++ & $--/+$ \\
\hline
\end{tabular}

Figuur 2 Beoordeling NH3 maatregelen op meervoudige effecten.

De volgende maatregelen zijn afgevallen:

- Extra weidegang. Extra weidegang wordt al sterk door de zuivelfabrieken gestimuleerd. Opname in het pakket zou leiden tot een dubbele prikkel. 
- Minder jongvee. Deze maatregel is alleen gunstig effect (= minder stalemissie) als ie wordt gecombineerd met aangepast voerbeleid, op bedrijven zonder mestafvoer. Daarnaast is de maatregel economisch aantrekkelijk waardoor deze sowieso genomen zal worden en dus geen extra stimulans behoeft.

- Verdunnen mest in de kelder. Deze maatregel is niet aantrekkelijk als er een kans is dat je aan het eind van het seizoen mest moet afvoeren. Boeren kiezen liever voor verdunnen tijdens het uitrijden. Afhankelijk van het borgingsmechanisme kan verdunnen in de kelder in de toekomst mogelijk alsnog.

- $\quad$ Netjes en op juiste moment uitrijden onder optimale weersomstandigheden (dus niet uitrijden bij zonnig weer en niet bij veel wind). De borging van deze maatregelen is (nog) te complex

- Diverse harde maatregelen (ACNV, dakisolatie, emissiearme vloer, luchtwasser) die gepaard gaan met investeringen. Voor investeringen zijn veelal andere regelingen opgetuigd. 

